\section{Atrizes da roça ou trabalhadoras rurais? O teatro e a fachada para obtenção da aposentadoria especial rural}

Recebido: 04.01.16

Aprovado: 13.06 .16
Eveline Lucena Neri \& Loreley Gomes Garcia*

Resumo: Este artigo trata das desigualdades de gênero no discurso judicial e nas operações práticas no âmbito dos juizados especiais federais. O julgamento dos processos de aposentadoria especial rural compete principalmente aos juizados especiais federais (JEFs). Para o deslinde dos casos, os magistrados precisam decidir se o autor da ação é segurado especial rural, tarefa esta que envolve uma série de conceitos legais e interpretações subjetivas no microcosmo da prática judicial. Com base na teatrologia de Erving Goffman, foram analisadas entrevistas, audiências e sentenças dos JEFs paraibanos capturando desigualdades de gênero no discurso dos atores participantes da interação social. Particularmente, foram estudadas as compreensões dadas ao trabalho e ao trabalhador rural individualmente ou em regime de economia familiar. Observou-se que as ideias de "trabalho leve" e "trabalho pesado" funcionam como "tecnologias de gênero" à medida que permitem qualificar e regular quem é o segurado especial rural, inserindo-o numa fachada social familiar e previsível, porém muito restrita e consequentemente geradora de injustiças em potencial.

Palavras-chave: agricultura familiar, discurso judicial, teatrologia, tecnologias de gênero, aposentadoria rural feminina.

\section{Introdução}

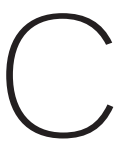

ategoria por algum tempo esquecida, desprestigiada no contexto da produção em larga escala, como demonstra Maria Ignez Paulilo (2004), a agricultura familiar é responsável por parte considerável da produção de alimentos que abastece o mercado nacional e corresponde, genericamente, ao trabalho rural produtivo exercido pelo grupo familiar numa pequena propriedade. As estratégias produtivas das famílias rurais não obedecem meramente à lógica econômica, e sim englobam relações sociais e diferenças de gênero que tendem a destinar um lugar inferior ao trabalho feminino, mesmo quando exercido em atividades consideradas "tipicamente" masculinas. Levadas aos processos através da tecnologia "trabalho leve" e "trabalho pesado", essas diferenças de gênero acabam participando da valoração das provas e produzindo resultados bastante subjetivos e, por vezes, arbitrários.

O artigo 11, inciso VII, da Lei 8.213/91, em síntese, considera segurado especial com direito à aposentadoria por idade, a pessoa física residente do imóvel rural até

\footnotetext{
* Eveline Lucena Neri é professora doutora do curso de direito da Universidade Federal da Paraíba, coordenadora do Núcleo de Estudos e Pesquisas sobre Gênero e Direito. <eveline.neri@gmail. com>.

Loreley Gomes Garcia é professora titular da Universidade Federal da Paraíba junto ao Programa de Pós-Graduação em Sociologia da UFPB. < loreleygg@gmail. com>.
} 
1. Parece haver menor número de audiências nos processos de aposentadoria especial rural que tramitam nos estados do Sul e Sudeste. Embora não haja estatísticas que comprove e explique essa diferença, alguns magistrados entrevistados com experiência anterior na Justiça Federal dessas regiões relataram o fato. A explicação mais plausível é que as petições iniciais nas regiões Sul e Sudeste sejam ajuizadas com mais provas documentais acerca da condição de segurado especial do autor, como aquelas que comprovam a filiação antiga aos sindicatos dos trabalhadores rurais e recibos da venda de excedentes da produção rural de diversos períodos. Este é um tema a ser aprofundado em outras pesquisas. quatro módulos fiscais ou em aglomerado urbano ou rural próximo a ele que comprove o exercício de atividade - agropecuária, de seringueiro, extrativismo vegetal, de pescador artesanal ou a este assemelhado - sozinho ou em regime de economia familiar por período correspondente a 180 meses, desde que atingidos 55 anos de idade para as mulheres e 60 anos para os homens. A referida lei entende por regime de economia familiar a atividade em que o trabalho dos membros da família é indispensável à própria subsistência e ao desenvolvimento socioeconômico do núcleo familiar e é exercido em condições de mútua dependência e colaboração, sem a utilização de empregados permanentes. E para serem segurados especiais, os membros da família precisam ser maiores de 16 anos e participarem ativamente nas atividades rurais do grupo familiar.

A despeito de os direitos dos segurados especiais terem se tornado exequíveis desde 1991, com a regulamentação federal dos benefícios previstos na Constituição Federal de 1988, foi através dos juizados especiais federais (JEFs) que o acesso à justiça dos segurados logrou grande avanço. Instituídos pela Lei 10.259, de 12 de julho de 2001, os JEFs, que podem ter competência plena, apenas cível ou somente criminal, têm atuação nas causas de baixa relevância econômica e menor potencial ofensivo, primando pela celeridade, oralidade e efetividade da prestação jurisdicional ao estabelecer rotinas que aproximam a população da Justiça Federal e que buscam a conciliação. Os processos relativos aos direitos previdenciários do trabaIhador rural correspondem à maioria das ações que tramitam nos juizados especiais cíveis, de modo que a avaliação sobre a qualidade de segurado especial rural é de fato uma rotina dessas varas judiciais.

Em muitos tipos de ações e matérias da Justiça Federal, as provas documentais são suficientes para formar o convencimento do magistrado sobre o assunto, a fim de proferir seu julgamento. Diz-se que são "matérias exclusivamente de direito". Trata-se da clássica divisão da doutrina em ações processuais "exclusivamente de direito" (isto é, matérias cujas provas requeridas à solução do caso são todas documentais e apresentadas previamente) e "matérias de fato" (assuntos cuja solução requer a produção de provas no curso do processo, a exemplo de depoimentos e testemunhos).

No cotidiano, dos JEFs paraibanos, os processos relativos aos segurados especiais rurais são desta segunda espécie. É frequente ${ }^{1}$ a necessidade da audiência de conciliação e de conciliação, instrução e julgamento (CIJ). O objetivo principal da CIJ é complementar o conjunto probatório sobre a condição de segurado especial rural do autor, produzindo-se perante o juiz e com oportunidade de intervenção das partes, provas orais, basicamente o depoimento pessoal do autor e de uma testemu- 
nha capaz de atestar a profissão de trabalhador rural pelo período requisitado à concessão da aposentadoria.

Ora, a incursão no discurso judicial evidencia, primeiro, que a clássica distinção entre matérias "exclusivamente de direito" e "de fato" esconde a vasta "zona de penumbra" sobre a interpretação tanto das leis quanto dos fatos. Segundo, revela a supremacia exercida pelo magistrado perante o autor, os advogados e demais envolvidos no discurso judicial. Em estudo sobre as representações do princípio do livre convencimento motivado dos juízes brasileiros, Regina Lúcia Teixeira Mendes da Fonseca (2008) identificou que as categorias "princípio do livre convencimento do magistrado" e "princípio da iniciativa probatória" - inspiradas na própria legislação brasileira e reproduzidas nas falas dos magistrados - são complementares e instrumentalizam um discurso judicial hierarquizado em que o magistrado em busca da "verdade real" dirige a produção de uma série de provas através das quais pretende formar suas conviç̧ões e julgar o caso. Conforme, Regina Fonseca:

Segundo a representação dos juízes entrevistados existe uma articulação indissociável entre as categorias de verdade real e justiça, o que torna para eles impossível atingir o livre convencimento sem, a seu critério, buscar novas provas ou esclarecimentos sobre as que já constam dos autos. Assim, sem o exercício da iniciativa probatória - ainda segundo os depoimentos dos juízes - é impossível atingir a verdade real por eles buscada, condição indispensável, segundo sua representação, para a realização da justiça (Fonseca, 2008: 251).

Com efeito, na rotina dos JEFs paraibanos, a ClJ é o centro da produção probatória e da interação entre as partes. É nela que ocorre o face a face, em que o magistrado inquirindo o autor, bem como as testemunhas, sempre permitida a elaboração de perguntas pelo advogado do autor e pelo procurador federal, busca formar sua convicção sobre a condição de trabalhador rural do autor e se todos os requisitos para a concessão da aposentadoria por idade estão preenchidos. A interação entre os participantes não é livre, nem igualitária. Há claramente uma hierarquia demonstrada desde a disposição da mobília até o modo inquisitório com que o magistrado dirige a audiência ao compor o cenário e a performance adequados à interação social semelhantes ao modelo da teatrologia de Goffman, ao qual nos referiremos adiante.

Exemplo disso é a disposição das salas onde são realizadas as audiências. Sob a direção do magistrado, o diálogo é travado entre as partes num ambiente formal. A organização das mesas é em forma de T. Na extremidade ficam o magistrado e seu assessor com computadores e microfones à disposição. A oralidade é privilegiada a 
partir da gravação em áudio das audiências e sentenças prolatadas e anexadas ao processo. Durante seus depoimentos, o autor e as testemunhas precisam sentar em frente ao magistrado e de costas para as partes, a fim de que não haja interferências nem intimidações com gestos e olhares. Na maioria das vezes, os magistrados reproduzem as perguntas feitas pelo advogado e pelo procurador federal para evitar deturpações da oitiva. Alguns magistrados, contudo, permitem que o autor e a testemunha respondam diretamente à indagação feita pelos procuradores do autor e do INSS.

Como discutiremos adiante, a busca da celeridade, um dos princípios norteadores dos juizados especiais federais, acaba por institucionalizar práticas judiciais que apresentam os indivíduos e seus modos de vida numa fachada social muito estrita, pobre em termos de experiência e potencialmente geradora de decisões injustas, a despeito de, em números absolutos de benefícios concedidos, os JEFs terem ampliado substancialmente o acesso à Justiça.

Ponto positivo dos JEFs é que os magistrados, habituados às audiências em processos de segurados especiais, esforçam-se em usar linguagem simples, acessível, de modo a se fazerem compreendidos pelas partes, especialmente pelo autor e pelas testemunhas, que muitas vezes possuem baixa escolaridade. Às vezes, o magistrado repete uma questão de diversos modos para que o depoente entenda o que está sendo perguntado.

Foi nesse microcosmo das práticas e decisões proferidas pelos JEFs paraibanos que foram capturadas as desigualdades de gênero. Os dados, os discurso processual e as entrevistas foram analisados, assim, na tentativa de perceber se existem e quais são as representações dos magistrados sobre os homens e as mulheres que se enquadram na condição de segurados especiais rurais. Com exceção da idade mínima necessária, os demais requisitos legais, que devem ter ao menos indício de prova material e/ou prova testemunhal, comportam certa margem de livre valoração pelos magistrados na hora de adequá-los ao caso concreto. E aqui pode residir toda espécie de preconcepções, as representações sociais sobre o que é o trabalho rural e por quem ele é realizado.

A pesquisa qualitativa empreendida coletou como dados áudios de audiências, sentenças escritas e entrevistas semiestruturadas com magistrados dos Juizados Especiais Federais (JEFs) da Paraíba. Foram selecionados aleatoriamente, num universo de cerca de mil processos levantados pelo sistema processual CRETA, cem processos dos juizados paraibanos, sendo analisados aqueles cujo benefício requerido foi a aposentadoria especial rural por idade em razão da atividade agropecuária indivi- 
dual ou em regime de economia familiar, com audiência de conciliação, instrução e julgamento $(\mathrm{CIJ})$ realizada.

A metodologia aplicada consistiu no modelo de abordagem teatral da vida social institucional oferecida por Erving Goffman (2002), em A representação do eu na vida cotidiana. Goffman oferece um referencial teórico e metodológico adequado às situações de interação social, definida pelo autor como "a influência recíproca dos indivíduos sobre as ações uns dos outros, quando em presença física imediata". Nessa interação face a face, como é o caso das audiências, cada ator desempenharia papéis sociais, representaria almejando influenciar a impressão que os demais participantes da interação dele terão. Buscou-se compor um quadro referencial da interação entre os participantes das audiências de ClJ e das representações que os magistrados têm das partes autoras através das falas e dos comportamentos registrados nos áudios das audiências, nas sentenças e nas entrevistas com os juízes e juízas.

Para Goffman (2002), quando um indivíduo chega à presença de outros, estes procuram logo conhecê-lo, conseguindo informações a seu respeito ou trazendo à baila aquelas que já possui. Boa parte das vezes, a curiosidade persegue razões práticas, a fim de criar um padrão para saber o que esperar da pessoa que se apresenta e como agir para obter dela as respostas de que necessita. Sendo a interação uma situação dinâmica e passível de confirmações, bem como de desconfianças e rupturas, a performance dos atores transforma-se num dos pontos essenciais da perspectiva sociológica de Goffman. Nessa esteira, o agricultor não é mera figura passiva ou vítima, mas alguém que, participando ativamente da audiência, se esforça por manter a coerência e convencer o magistrado acerca do seu modo de vida e do exercício da atividade rural.

O magistrado, por seu turno, incapaz de ser neutro axiologicamente, opera uma série de preconcepções sobre o que é trabalho rural e quem é trabalhador rural apto a receber os benefícios. Apesar de o autor ser-lhe estranho, o juiz busca referências em processos anteriores de pedidos semelhantes para valorar as provas documentais, orais e "estéticas". As "regras da experiência" formam o estereótipo de quem é o segurado especial rural.

É na valoração das provas, necessária à avaliação da situação em julgamento, que participam as tecnologias de gênero, sendo estas, na perspectiva adotada por Teresa de Lauretis (1989), preconcepções disseminadas nos discursos culturais, científicos, artísticos etc. funcionando como chaves que formam nossa compreensão sobre os sexos. As tecnologias de gênero cumprem a dupla função de tornar compreensível e normalizar as diferenças produzidas sobre o masculino e o feminino (Lauretis, 1989)².
2. Foucault (1999) define as tecnologias sociais como mecanismos de poder encarregados de avaliar, medir, qualificar e regular os diversos aspectos da vida. A sexualidade, por exemplo, não é algo inerente aos corpos, mas processo e produto dos efeitos sobre os corpos que circulam através dos discursos e das práticas sociais. Inspirada na lição foucaltiana, Teresa de Lauretis (1989) propõe adotar o gênero como processo e produto de tecnologias sociais, percebendo as desigualdades nas condições de fala atribuídas e os diferentes papéis destinados às mulheres $\mathrm{e}$ aos homens nos discursos culturais. E por que não judiciais? 
A partir deste referencial teórico, procurou-se perceber se existem e como são operadas as tecnologias de gênero dentro das indagações sugeridas pelo próprio sistema legal, isto é, aquelas respostas que interessam aos magistrados, na prática, para definir a qualidade de segurado especial rural e, por conseguinte julgar seu pedido de aposentadoria especial rural.

As seguintes perguntas foram feitas:

O que é trabalho rural para fins de reconhecimento da qualidade de segurado especial rural?

Quem é trabalhador rural para fins de concessão da aposentadoria ao segurado especial rural?

Quais as concepções de regime de economia familiar no entendimento dos magistrados?

Tais são as indagações que norteiam o diálogo nas audiências e, por conseguinte o convencimento do magistrado e das partes. Para efeitos didáticos, podemos tratá-las separadamente, a fim de analisarmos os sentidos preponderantemente dados às categorias trabalho rural, trabalhador rural e regime de economia familiar.

Quanto à definição de trabalho rural, a hipótese foi que um universo muito amplo de atividades rurais é excluído ou relegado a segundo plano como atividade secundária em detrimento do trabalho no "roçado" e "com a enxada". O que inicialmente chamou atenção foi o fato de, apesar de a lei prever expressamente o termo "agropecuária", a referência majoritariamente encontrada nas peças, decisões e audiências é à "agricultura" entendida como "roçado". Quais as razões para tanto?

A questão de quem é trabalhador rural precisa ser esclarecida. Em verdade, interessa ao magistrado definir quem cumpriu todos os requisitos necessários à concessão da aposentadoria por idade, o que exige o exercício efetivo da atividade rural, atualmente pelo período, ininterrupto ou não, de 180 meses, na condição peculiar de segurado especial rural. Entretanto, na prática, certa intuição de quem é trabalhador rural está presente e ganha corpo na inspeção judicial. Em audiência, o magistrado avalia as características físicas e os comportamentos usuais do agricultor. A hipótese levantada foi de que o campo restrito de atividades consideradas e modos de vida conhecidos contribuiriam para aumentar a falibilidade da inspeção judicial e que isso acaba causando desigualdades de gênero.

Por sua vez, o conceito legal sobre o "regime de economia familiar" requer a construção de concepções interpretativas nos casos concretos. Isso porque a legislação 
estipula elementos extremamente subjetivos como "atividade em que o trabalho dos membros da família é indispensável à própria subsistência e ao desenvolvimento socioeconômico do núcleo familiar", que o labor seja exercido em "condições de mútua dependência e colaboração, sem a utilização de empregados permanentes" e que "para serem considerados segurados especiais, o cônjuge ou companheiro e os filhos maiores de 16 anos ou os a estes equiparados deverão ter participação ativa nas atividades rurais do grupo familiar".

\section{Discutindo os dados: trabalho leve e trabalho pesado no discurso judicial}

Maria Ignez Paulilo (1987) investigou o uso dos termos "trabalho leve" e "trabalho pesado" em diferentes regiões do país, entre as décadas de 1970 e 1980, entrevistando trabalhadores e habitantes rurais. No que concerne ao estado da Paraíba, as observações de Paulilo foram as seguintes:

Sertão de Paraíba, 1978, municípios de Pombal, São Bento, Brejo da Cruz, Catolé do Rocha e Riacho dos Cavalos. Predominam a pecuária e a cultura do algodão. Os empregados residentes das fazendas ("moradores") são parceiros em regime de meia e de terça: em troca do uso da terra, em geral entregam ao proprietário metade da produção de algodão e 1/3 do produto das outras lavouras. Trabalho "pesado" é a limpeza do mato e a criação de gado. Mulheres e crianças ajudam no plantio e na colheita das lavouras, cuidam das atividades domésticas e procuram complementar a renda familiar dedicando-se a ocupações artesanais como tecer linha, fazer acabamento de rede, fabricar chapéus e rendas... 0 pagamento desse "trabalho leve" e moroso, que exige habilidade e paciência, é ínfimo.

Brejo da Paraíba, 1978, municípios de Alagoa Nova, Areia, Pilões, Serraria e Arara. Aqui a distinção entre "trabalho leve" e "trabaIho pesado" se faz mais clara. Entre os trabalhadores volantes é "pesado", masculino, principalmente roçar a cavar a terra. Roçar significa derrubar o mato grosso, inclusive árvores, a machado e foice. Cavar é preparar a terra, sem ajuda do arado, para o plantio da cana. Trabalho "leve", feminino, é plantar, arrancar o mato miúdo, e adubar. Para isso, as mulheres ganham a metade, ou menos, da diária de um homem, embora trabalhem o mesmo número de horas. Nas fazendas onde há olarias rústicas, as mulheres carregam tijolos em carrinhos de mão, serviço também considerado "leve" e pago como tal. Nenhum homem é contratado para fazer trabaIho considerado feminino, embora algumas atividades possam ser realizadas por ambos os sexos. Pagando por produção, os proprietários evitam remunerar o tempo que as mulheres gastam com os filhos e o maior esforço que despendem para limpar uma mesma 
área de cana. Já nas atividades em que a força física não traz maior rendimento, como o plantio e a adubagem, evitam presença masculina para melhor caracterizá-las como "trabalho leve". Apesar da sutileza empregada na exploração da mão de obra feminina, há mulheres que, realizando as mesmas tarefas que os homens, ganham menos (Paulilo, 1987).

A pesquisa desmistifica a falsa crença de que o vocábulo "trabalho pesado" relaciona-se naturalmente à força e ao desgaste físico necessários para desempenhar o labor considerado, reservando-se o "trabalho leve" para os trabalhos manuais menos desgastantes ou que exigem menor vigor físico. Outro fator instigante é que aquilo que é considerado "pesado" varia de região para região (Paulilo, 1987).

Paulilo (1987) esclarece-nos que há uma divisão sexual do trabalho no campo construída culturalmente e reforçada pelos grandes empregadores rurais. Um conjunto variável de funções em cada região é atribuído ao homem e considerado "trabalho pesado" merecedor de melhores remunerações. Já as mulheres, especialmente as casadas, devem, em regra, ficar com o "trabalho leve", expressão que passa a impressão de que as atividades executadas pelas mulheres são aquelas de menor desgaste físico ou que requerem menos força.

No entanto, como demonstrou a autora, mais que a avaliação sobre o desgaste físico, o sexo de quem pratica a atividade é determinante à classificação do trabaIho "leve" ou "pesado". Isso porque quando residualmente a mulher trabalha no corte da cana é menos bem remunerada e, no caso das mulheres casadas do Brejo, que muitas vezes são responsáveis por todas as atividades do roçado, enquanto os maridos estão na lavoura de cana, desaparece a divisão entre limpar mato e cavar ("trabalho pesado", para o sertanejo), de um lado, e plantar e colher ("trabalho leve"), de outro, transformando-se todas essas atividades em "trabalho leve" ou "uma ajudinha".

A divisão sexual do trabalho no meio rural, nesse sentido, seria demarcada por tecnologias de gênero desvalorizadoras do trabalho realizado pelas mulheres. Este é considerado "leve" se feito pela mulher, qualquer que seja a espécie de atividade ou a força física empenhada. "Leve" significaria complementar, secundário, não remunerado ou sequer assumido como trabalho. Se a mulher trabalha no roçado junto ao marido, ela "dá uma ajuda".

A distinção entre "trabalho leve" e "trabalho pesado" é uma tecnologia de gênero que, levada às audiências através da petição inicial e da fala do(a) autor(a), tanto cria lugares fixos para as atividades rurais de homens e mulheres quanto estipula 
hierarquias, considerando sempre as ações "tipicamente" realizadas pelos homens como verdadeiro trabalho no campo. Nas relações cotidianas do campo, o trabalho feminino fora do roçado é visto como secundário ou complementar ao do marido, do pai ou dos filhos. E as audiências analisadas demonstraram a reprodução dessa tecnologia, sendo frequente todos os envolvidos na interação se referirem ao trabaIho feminino como "ajuda" ou acessório.

Como a legislação impôs o conceito de "regime de economia familiar", os magistrados consideram relevante identificar as atividades e a contribuição de cada um dos membros da família para o sustento familiar. A partir daí começam a surgir, na interação, as investigações em torno do trabalho urbano e trabalho rural.

O status civil do(a) autor(a) e o conjunto das ocupações dos membros familiares é tão importante que, às vezes, antes mesmo de indagar a(o) autor(a) qual sua profissão ou em que trabalha, os juízes perguntam se o(a) esposo(a) trabalha ou se já é aposentado e em quê. No caso das autoras, quando o esposo tem ocupação urbana ou é aposentado, alguns magistrados indagam logo: "e a senhora precisa trabalhar?"

No processo 2, a juíza perguntou o endereço do autor e quem morava com ele. Quando o autor respondeu que sua esposa morava com ele, a magistrada continuou indagando se a esposa trabalhava. O autor consentiu que sim e respondeu

- Ela me ajuda no trabalho.

- Trabalho de quê? (sic)

- No campo, né.

- E sua esposa já trabalhou com outra coisa?

A despeito de a legislação falar em "agropecuária", em nenhum dos processos estudados a parte alegou na petição inicial que vivia da criação de gado ou de outros animais e sempre que os magistrados inquiriam, em audiência, em que trabalhavam. As respostas invariavelmente eram: "na agricultura", "no roçado", "no campo". Por um lado, isso demonstra - como sustentou o entrevistado 7 - não ser muito comum os segurados especiais da Paraíba tirarem seu sustento exclusivamente da criação de animais, sendo bem mais frequente o trabalho na agricultura. De outro lado, por que não alegam exercer a agropecuária ou a criação de outros animais? Será que seu pedido seria de pronto negado?

Na entrevista 1, foi indagado ao magistrado: "O trabalho com animais ou o trabalho feito no quintal, como os cuidados com a horta, são trabalhos considerados rurais?" 
Olha, por exemplo, se o trabalhador tem só a criação de animais, a jurisprudência é bastante minoritária no sentido da concessão. Confesso que eu não lembro de ter visto jamais um caso em que a pessoa afirma que apenas tem criação de animais. Ele diz que tem, também, algumas cabeças de bode, de galinha, até de gado mesmo. Dificilmente ele vai dizer que tem só animais até porque ele tem advogado e se ele não for agricultor ele sabe que pelo menos vai ter que historiar de forma diferente (Entrevista 01).

A sequência de perguntas na entrevista 3 reforça o entendimento de que "atividade rural" para fins de qualificação do segurado especial é assemelhada à "agricultura":

- Esse trabalho de criação de animais é considerado atividade rural para fins de concessão da aposentadoria do segurado especial rural?

- Veja só. Qual o conceito de segurado especial? É aquele que exerce atividade rural com fins meramente de subsistência. Eventualmente, nada impede de criar galinhas. A atividade de criar galinhas é uma atividade acessória. Tem que ser visto no contexto. O que você faz? Eu crio galinhas. Criar galinhas não é algo que dê a ele pura e simplesmente a qualidade de segurado. É uma atividade acessória. A qualidade de segurado advém da atividade da agricultura, da pesca, em regime de economia familiar, ou seja, todos participam, todos trabalham e o resultado do trabalho é dividido para todos. Isso é que caracteriza o segurado especial. E ele é segurado especial justamente porque o regime previdenciário é contributivo, as pessoas realmente contribuem para receber determinado benefício. O segurado especial não contribui. Se ele contribuir, deixa de ser um segurado especial. Ele passa a ser um segurado facultativo ou obrigatório (Entrevista 03).

A criação de animais, na maioria dos casos, é tomada como um trabalho "acessório", que, a princípio, parece significar "restrito" ou "pouco frequente". No entanto, outras duas falas dos magistrados fazem surgir os sentidos de "complementar ao do marido" e "pouco significativo para o sustento familiar".

- Eu, particularmente considero. A mulher deve ter um tratamento especial porque, primeiro, a força física geralmente é menor. Depois, ainda que seja uma atividade simples, pode ser muito importante para seu sustento. Podemos definir como critério para não ficar completamente subjetivo: saber se aquela é a ocupação principal dela. A mulher, naturalmente (sic), vai ter ao menos duas atividades: doméstica e rurícola. Creio que quando ela é casada a situação fica muito mais simples porque ela está ajudando o marido na atividade rurícola, por exemplo se estiver em casa preparando a alimentação daqueles que irão trabalhar no campo. Há 
uma extensividade. A gente só não pode conceder se perceber que não há nenhum vínculo da esposa com o trabalho rurícola (Entrevista 04).

Observa-se que a pergunta acerca das atividades da mulher no quintal acaba se transformando em exemplos de atividades complementares às atribuições masculinas, assumindo que elas não são domésticas e sim rurais, pois estão relacionadas às necessidades do esposo no meio rural. Atrela-se o trabalho rural à centralidade dele para a "sobrevivência" do grupo familiar, acreditando que a criação de animais não é uma atividade importante a ser considerada. A atividade feminina, assim, não é reconhecida por si, mas em dependência às do marido.

O entendimento acima esposado, assim, privilegia a "labuta na roça" como atividade principal. Em outro momento, o entrevistado 2 expressou também que a criação de animais pela mulher é atividade "secundária" ou "complementar" independente de servir ao consumo ou à venda. Assim, caso a mulher exerça a agricultura e tenha uma "hortinha" ou crie animais, sua atividade principal será a agricultura e as demais "secundárias" ou "complementares". Se ela exercer meramente as atividades "complementares" não será segurada.

A ideia de atividade pouco importante economicamente, portanto, esconde o fundo da questão que é a desvalorização das atribuições tipicamente exercidas pelas muIheres e a crença sempre latente da dependência econômica das esposas e filhas. O trabalho rural é enquadrado numa fachada social cujo horizonte é limitado pelas atividades consideradas "pesadas". Em vários processos, os termos "agricultura", "roça", "trabalho com enxada" e "trabalho pesado" são usados como sinônimos, em franca redução da realidade social de trabalho rural.

É preciso entender que as estratégias de ação produtiva das famílias respondem a outros fatores além do econômico, como o cultural, e seguem normas sociais tradicionalmente repassadas. As desigualdades de gênero no âmbito familiar, por exemplo, traduzem as relações de poder que fazem com que haja entre os componentes da família uma ordem hierárquica. Papéis e limitações são atribuídos a cada cônjuge, filhos e filhas, forjando assim tanto a divisão sexual do trabalho quanto a administração da família e das rendas por elas percebidas.

Numa ligação bastante capciosa sobre a determinação do que deve ser trabalho masculino e trabalho feminino está a ideia de "proteção" feminina. Ela tanto serve para tornar obrigação do homem ser arrimo de família, quanto para limitar e desva- 
lorizar as atividades destinadas às mulheres. O trabalho externo das esposas e filhas, incluindo as profissões de cortadora de cana e de vaqueira, é reprovado não apenas pelo desgaste físico, mas principalmente para que elas não tenham contato com outros homens e, ao mesmo tempo, mantenham-se cerca de casa, a fim de executar as tarefas "domésticas", entendidas nestas a criação de animais e a horta no quintal da residência. No meio rural, a hierarquia familiar que subordina as mulheres se reproduz através de ideologias e práticas, por exemplo, a tendência de desenvolver atividades próximas à residência para não ter contato com homens estranhos à família e poder, simultaneamente, desempenhar o labor doméstico (Rufino \& Albuquerque, 1986). Nesse sentido, Portella e Silva (2006) apontam a maior dificuldade de as mulheres rurais se inserirem no espaço público.

A tecnologia "trabalho leve" e "trabalho pesado" permeia também as falas dos juízes. O seguinte diálogo extraído de audiência de instrução e julgamento (Processo 06) revela bem esse fato:

3. Mas o que é a inspeção judicial? Tecnicamente, 0 Código de Processo Civil, Lei no 5.869 de 1973, estipula em seu art. 440: "O juíz, de ofício ou a requerimento da parte, pode, em qualquer fase do processo, inspecionar pessoas ou coisas, a fim de se esclarecer sobre fato, que interesse à decisão da causa". Trata-se, assim, a inspeção judicial da previsão de contato direto do magistrado com uma pessoa ou coisa, a fim de esclarecer detalhes de um fato auxiliando-o na sua interpretação.
Magistrado - A senhora trabalha com enxada, faz serviço pesado mesmo na roça?

Autora - Sim, mas há cerca de um ano não pego em enxada por causa da diabetes, faço mais plantar.

Magistrado - Quem faz o serviço doméstico?

Autora - Eu mesma quando volto do roçado.

Magistrado pergunta à testemunha - Ela trabalha na enxada mesmo, não trabalha na colheita ou no plantio?

Testemunha - Trabalha com enxada (Processo 06).

Assim, "trabalho leve" e "trabalho pesado", perfil de agricultor rural, pele queimada de sol e mãos calejadas, trabalho na roça com enxada são expressões comumente repetidas pelas partes e pelos magistrados que se comportam como tecnologias de gênero ao restringir a pluriatividade dentro e fora da propriedade rural. Para Neves e Costa (2008), o trabalho feminino na agricultura comumente é tido como "ajuda". O trabalho no quintal, isto é, a criação de animais e a administração da horta são consideradas tarefas domésticas. E os trabalhos doméstico e de cuidado com crianças, doentes e idosos sequer é pensado como trabalho, sendo mera obrigação ou coisa de mulher, por mais exaustivo ou importante que seja para a composição da renda familiar.

A produção das provas em audiência é determinada, sobremaneira, por essa compreensão do trabalho rural como sinônimo de trabalho na roça, labor com enxada. Nesse sentido, as entrevistas e os processos estudados demonstram que duas pro- 
vas são consideradas essenciais pela maioria dos magistrados: o conhecimento das técnicas e dos instrumentos de trabalho. A inspeção judicial ${ }^{3}$ parte do pressuposto restrito do trabalho no roçado.

No processo 2, por exemplo, a magistrada indagou ao autor:

- O senhor planta o quê lá?

- Feijão, milho, macaxeira.

- Planta milho-alho? Planta macaxeira?

- Planto.

- E a macaxeira o senhor planta quando? É na mesma época do milho ou o senhor planta depois? Como é que o senhor faz com a macaxeira? Quando é que o senhor vai plantar macaxeira?

-A macaxeira planto primeiro porque ela demora mais que o miIho. Logo nas primeiras chuvas de janeiro (Processo 02).

A mesma espécie de quesitos é feita às mulheres que alegam serem agricultoras (Processo 5):

- Desse tempo que a senhora voltou, a senhora tá fazendo o quê? - Trabalhando né, na roça, agricultura, plantamos fava, milho, feijão.

- A senhora plantou o quê?

- Até agora nada.

- Este ano não, eu estou perguntando ano passado?

- Milho, feijão, fava, feijão-macáçar.

- Milho, qual o milho? A senhora planta milho-alho?

- Milho-alho não.

- É lerão ou cova que a senhora planta? Quando é que o terreno é bom para plantar batata?

Num diálogo de respostas mais livres, o magistrado interroga a autora (Processo 10):

- Como é o trabalho na roça?

- De limpar mato, de plantar.

- Como é que a senhora faz? Descreva seu trabalho no roçado.

- De plantar?

- Sim.

- Planto milho, planto feijão...

- Não. Eu quero saber como é que a senhora prepara a terra.

- Meu irmão me ajuda a preparar, aí eu planto. 
- Com que instrumento?

- Com a enxada. Planta, limpa.

- Quantos caroçinhos a senhora joga em cada um?

- Dois, três, até quatro.

- Em quanto tempo dá milho? Em quanto tempo dá feijão?

- Se for ligeiro são uns três meses.

- E se não for ligeiro?

- Uns quatro meses.

- Quantas espigas dá num pé de milho?

O padrão de questionamentos sobre as técnicas e os instrumentos utilizados para o trabalho na agricultura é bastante difundido nos JEFs da 1. a e 5. a regiões. Conforme Aquino et alii (2012), as perguntas dos juízes sobre a rotina de trabalho no campo bem como a inspeção judicial nas mãos da parte à procura de calosidades configuram um padrão nos JEFs dos TRFs dessas regiões:

- Quantas espigas dá um pé de milho?

- O senhor sabe a diferença entre a mandioca brava e a mandioca mansa?

- O senhor já cuidou de galinha? Quanto tempo demora pra galinha chocar o ovo?

- Quantas sementes o senhor joga na cova quando vai plantar o milho?

- O senhor já tratou de porco? Quantas vezes por dia o senhor dá comida para o porco? Quantos porcos nascem de uma cria?

- O senhor tem vaca? Quantos litros de leite tira da vaca por dia? (Juizados, 1a e 5a Regiões) (Aquino et alii, 2012: 141).

Ressalte-se que, das perguntas acima registradas por Aquino et al (2012, p.141), extrai-se um espaço mais amplo de trabalho rural considerado, qual seja, a criação de animais. Contudo, o trabalho na horta ou o cultivo de plantas no quintal continuou sem registro.

Trata-se do padrão sexista disseminado no meio rural, que coloca a mulher numa posição de fragilidade e subordinação inclusive no modo de organização do trabalho intrafamiliar. Se vão à roça, devem ir na companhia do esposo ou de filhos homens, sob a direção destes. Essa constatação é conhecida dos magistrados federais.

Cumpre salientar um aspecto sobre as mulheres, a mulher não sabe por que ela faz o que homem, o marido, o pai, enfim o líder do roçado determina. Ele diz o tempo bom para a colheita, como deve ser plantado, o que deve ser plantado. Ela mais ou menos 
segue as orientações dele e daí vem a dificuldade de na hora da audiência (isso não é uma regra, mas uma constatação a partir de alguns processos) mulheres que efetivamente são agricultoras dizerem qual o período de colheita do feijão, qual o procedimento adequado, porque elas apenas cumprem regras (Entrevista 02).

A cultura da companhia masculina é tão arraigada que, em geral, causa estranheza aos magistrados a alegação da mulher que afirma exercer atividade rural enquanto o cônjuge ou companheiro é aposentado por atividade urbana. Por experiência, eles sabem que há maior probabilidade (não certeza) de a mulher não trabalhar na agricultura, girando o centro de vida e de trabalho do casal na zona urbana. Enquanto a aposentadoria já percebida por um dos membros do casal pela esposa ou pelo esposo, como segurado especial rural intui semelhante labor do outro cônjuge, a aposentadoria urbana do esposo, por seu turno, acarreta desconfiança sobre o exercício da atividade rural feminina.

É bem verdade que não se pode tachar precipitadamente de injustiça de gênero os exemplos tratados. Afinal, o magistrado segue padrões definidos em lei e em jurisprudência, além de suas próprias conviç̧ões e intuições. No entanto, a improvável labuta sozinha da mulher casada na roça é assumida como um indício negativo, ou melhor, um precedente responsável por direcionar o decorrer do diálogo, aumentando o rigor da avaliação do magistrado sobre técnicas e instrumentos de trabalho na agricultura e exigências quanto ao estereótipo esperado da parte autora.

Deve-se ainda acrescentar o rigor do juiz para que a parte autora se enquadre numa fachada social sem entrar em contradição consigo ou com o dito pela testemunha. Fachada esta que não incorpora a complexidade das relações sociais, de trabalho e de gênero das famílias rurais. Parcial e falha, portanto. Dentre os indícios ou provas do trabalho rural indicados pela maioria dos entrevistados dos JEFs paraibanos estão ainda as "marcas" deixadas no corpo do(a) agricultor(a) ao longo dos anos e avaliadas durante a inspeção judicial.

Ao lecionar sobre a inspeção judicial, Luis Fernando Nardelli (2008) expressa o entendimento de que a inspeção judicial propicia ao magistrado um conhecimento direto sobre as coisas e as pessoas. Referida assertiva é ingênua tendo em vista que a inspeção judicial é exatamente fruto da representação do magistrado sobre o(a) autor(a) do pedido, com base na performance deste em audiência e levando em consideração sua experiência anterior com outros segurados. As inspeções judiciais são, em verdade, avaliações extremamente subjetivas que ganham um padrão a partir de uma fachada social construída na prática judicial: 
Pele queimada pelo sol, mãos calejadas... exige certa sensibilidade. Não há um único motivo que caso verificado reprove o pedido, mas é preciso colocar tudo isso dentro de um conjunto. Olho os pés, as mãos, o tom da pele, as marcas deixadas pelo sol... O trabalho na agricultura é um trabalho eminentemente braçal, então uma pessoa extremamente gorda ou extremamente obesa teria dificuldade de receber o benefício, isso porque ela não se adapta àquele tipo de atividade, especificamente àquele tipo de trabalho. Ou ou [pausa] não significando que uma pessoa obesa não poderia receber, mas são analisadas as características físicas como um todo (Entrevista 03).

Na fala acima, a obesidade por si só é colocada como óbice ao reconhecimento do trabalho rural. Ela não se enquadra no conjunto de elementos que compõem a fachada do(a) segurado(a) especial.

Ao relembrar a teatrologia de Goffman (2002), a representação da cada ator se dá dentro de uma fachada social, isto é, a performance é executada através de um conjunto de elementos estereotipados que são familiares aos participantes e tornam compreensíveis as atuações das partes. A fachada social é subdividida em cenário e fachada pessoal. O cenário corresponde ao espaço físico onde a atuação ocorrerá e serve para fixar a posição em que a representação se dará. A disposição da mobília, o luxo ou a simplicidade da decoração. Tudo isso compõe o cenário e gerará informações à representação. Já a fachada pessoal diz respeito aos equipamentos expressivos caracterizadores do ator e que geralmente o acompanham onde quer que vá:

Entre as partes da fachada pessoal podemos incluir os distintivos da função ou da categoria, vestuário, sexo, idade e características raciais, altura e aparência, atitude, padrões de linguagem, expressões faciais, gestos corporais e coisas semelhantes (Goffman, 2002: 31).

É possível ainda, didaticamente, distinguir a fachada pessoal em aparência e maneira, conforme a função informativa de cada uma dessas espécies de estímulos expressivos (Goffman, 2002: 31). A aparência informa acerca do status social do ator, bem como identifica a atividade que realiza no momento, determina se está de lazer ou o labor que exerce. A maneira engloba os comportamentos que denotam o papel que o indivíduo pretende exercer perante outros participantes da interação, especialmente se age arrogantemente, tentando dirigir o diálogo ou se espera ser dirigido numa posição de humildade. Dizemos que aparência e maneira são coerentes quando o ator atua dentro dos padrões esperados. 
Desse modo, os magistrados acreditam que a pele queimada e com manchas de sol, as mãos calejadas, um "certo odor", a vestimenta e a linguagem utilizada pelos agricultores podem ser percebidos diretamente a partir de sua vasta experiência com outros agricultores, sendo uma prova difícil de ser fraudada. A aparência e as maneiras ajudariam sobremaneira a contar a história de vida e trabalho das partes.

Eu não vou à audiência com um posicionamento pré-definido pela prova documental... São duas coisas diferentes: o contato pessoal e a coerência. A coerência tem a ver com a parte não entrar em contradição, trazer um posicionamento uníssono com o que ela disse, com o que a testemunha disse, com o que está na exordial e até também com o que foi dito na entrevista com o INSS (Entrevista 01).

Existem marcas do tempo pra mim que dificilmente são forjadas. Então, por exemplo, os calos nas mãos, as mãos amareladas, a pele bastante queimada do sol, marcas de sol também nos pés, os calos até nas laterais das mãos próprios também do trabalho com enxada... Claro que como tudo na vida esses elementos podem ser objeto de fraude... Uma hora até essas marcas pessoais podem chegar a ser fraudadas... É uma prova mais difícil de ser forjada do que uma prova documental (Entrevista 01).

Indagado se existem outros tipos de trabalhos em que essas marcas não ficam bem definidas, o entrevistado 1 respondeu:

Há alguns tipos em que as características são semelhantes, por exemplo, o trabalho de pedreiro. Também é feito muitas vezes sob o sol. Também exige força física, as mãos ficam marcadas. Há também outras marcas como a fala, a peculiaridade da fala do agricultor, do sertanejo que o juiz também pode identificar e pender seu julgamento para a procedência (Entrevista 01).

O elemento de prova frequentemente referido nas audiências e sentenças foi o calo nas mãos. "Deixa eu ver suas mãos para ver se o(a) senhor(a) tem mãos de agricultor(a)" é uma frase que, guardadas algumas variações e exceções, aparece rotineiramente nos processos de aposentadoria do segurado especial rural. Passagem interessante ocorreu no processo 20 em que diante de um procurador do INSS inexperiente nos processos que envolvem segurados especiais o magistrado ensinou o procurador a identificar o calo típico do trabalho com a enxada:

Procurador - Eu posso ver as mãos da senhora?

Juiz - Doutor, segundo um colega seu com quem aprendi muito quando comecei a carreira o calo da mão é bem aqui! (Processo 20). 
O entrevistado 2 também se pronunciou no sentido da relevância probatória dada ao contato pessoal com a parte:

Depois, é o aspecto físico. Aliás esse é sempre o elemento preponderante. $\mathrm{O}$ aspecto físico, o odor característico, mãos calejadas, pele curtida pelo sol. Merece o registro que geralmente isso é encontrado no homem. É mais fácil encontrar tais características físicas do trabalho de agricultor no homem porque geralmente é ele quem exerce as atividades mais pesadas. Quando as mulheres têm essas características fica mais claro, mas geralmente não têm. Algumas mulheres têm os braços mais musculosos, principalmente as mais jovens. $E$ as mais velhas, são traços do sol, pele curtida e estragada pelo sol, marcas do vestido ou da roupa que esteja usando... (Entrevista 02).

O ponto crucial colocado de que é mais fácil encontrar as características físicas nos homens porque geralmente estes desenvolvem os trabalhos "pesados", "com enxada", leva-nos novamente às influências da tecnologia "trabalho leve" e "trabalho pesado" no processo judicial. Ora, uma vez reduzido o conjunto de atividades praticadas no meio rural àquelas exercidas no roçado com o auxílio da enxada, aumenta-se o prejuízo potencial de buscar o calo da enxada em todos os autores, especialmente nas mulheres cujas atividades preponderantes não foram executadas ao cabo da enxada.

No processo 06, os efeitos da tecnologia de gênero "trabalho leve" e "trabalho pesado" recaem tanto sobre o corpo da autora quanto sobre as relações familiares em jogo, pressupondo o magistrado a dependência econômica da esposa em relação ao marido, de acordo com o seguinte excerto da sentença:

A autora não possui nem um pouco características físicas próprias de uma trabalhadora do roçado, com mãos calejadas ou pele queimada ou maltratada pelo sol ... Indício de prova negativa o fato de o esposo da requerente ser pastor e receber cerca de $\mathrm{R} \$ 1.000,00$ mensais em dízimos, além de receber aposentadoria urbana pelo INSS (Processo 06).

A pluriatividade familiar, assim, tem recebido uma leitura prejudicial ao reconhecimento da aposentadoria especial rural das mulheres casadas quando o esposo possui ocupação urbana. É como se as relações de gênero que participam da divisão sexual do trabalho na família rural fossem levadas ao extremo e tornadas parâmetros de julgamento para um número amplo de casos. A comum subordinação da mulher no ambiente familiar é transformada em pressuposição de sua dependência econômica. 
O modo de produção individual ou em regime de economia familiar é, na maioria das vezes, a primeira caracterização que vem à baila no momento da audiência. Em geral, no regime de economia familiar, entende-se que a venda do excedente da produção pode ocorrer ocasionalmente, especialmente nas épocas de safra, mas o sustento principal da família advém do consumo daquilo que ela produz ou de outra fonte de renda de um dos membros considerada valor suficiente para a sobrevivência da família.

Do cotejo das entrevistas e processos analisados, observa-se que as ficções de solidariedade econômica entre os cônjuges, dependência financeira das mulheres casadas em termos abstratos e o caráter tomado pelos magistrados como predominantemente assistencial do benefício de aposentadoria conferida ao segurado especial rural são os principais pontos que definem a interpretação conjunta da pluriatividade e do regime de economia familiar.

A respeito do tema das ocupações na zona rural, Schneider (2003) propõe o uso do conceito de "pluriatividade". O autor ressalta que, na década de 1980, os termos part-time farming (agricultura em tempo-parcial) e pluriactivité (pluriatividade) eram adotados por cientistas sociais ingleses e franceses, respectivamente, como se fossem sinônimos, sendo que somente nas décadas seguintes passaram a ser vislumbradas diferenças semânticas e teóricas reunidas nos vocábulos abordados. Enquanto full-time farming e monoactivité parecem ter conteúdo semelhante, isto é, significam que todas as horas de trabalho familiar são empregadas nas atividades agrícolas, part-time farming e pluriactivité referem-se a assuntos distintos. O primeiro afere o tempo dedicado à atividade agrícola, confundindo o espaço físico com os próprios ocupantes da unidade doméstica. O último centra-se na diversidade das atividades e fontes de renda dos membros da família, observando também a gestão do trabalho doméstico e as relações intrafamiliares, considerando mesmo os novos padrões de relações sociais entre homens e mulheres.

As vertentes que explicam a pluriatividade como estratégias de ações do grupo ou de seus indivíduos parecem mais promissoras que a mera preocupação com a divisão sempre arbitrária das atividades em agrícolas e não agrícolas, por estarem adequadas às vivências experimentadas pelas famílias rurais nordestinas. Diante do pouco acesso à tecnologia, à terra e das adversidades naturais, os nordestinos precisam se reinventar para escapar à fome: "homem, a vida de pobre é muito difícil. A gente tenta escapar de todo jeito."

Principalmente a perspectiva que cinde as estratégias e os rendimentos obtidos pelos entes familiares, conferindo-Ihes autonomia de gestão (Silva \& Schneider, 2010) 
são mecanismos eficientes para perceber as fissuras nas relações patriarcais que dirigem as famílias rurais, bem como são ferramentas de análise dos dados coletados na pesquisa.

Já a legislação e boa parte da jurisprudência partem do prisma oposto, ou seja, da família como unidade de trabalho indivisível e de pessoas indistintas, considerando apenas a atividade agrícola para a subsistência. Referida concepção tem obstado, nos casos concretos, a concessão de aposentadoria quando alguns entes têm vínculo formal de trabalho não agrícola, sem ver o conjunto das estratégias familiares ou das histórias individuais. Como veremos na análise dos autos coletados, carteira de trabalho assinada, atividades de comércio de um dos membros etc. certas vezes são fundamentos para o indeferimento do benefício de aposentadoria especial rural de outro componente da família pelo magistrado. Além disso, o trabalho feminino na agricultura não raramente é visto como complementar ao do marido ou companheiro, ficando mais difícil a concessão do benefício à mulher quando o cônjuge exerce ou exerceu atividade laboral não agrícola.

Embora a própria jurisprudência já tenha se preocupado em afastar a descaracterização da esposa como segurada pelo motivo por si só de o marido trabalhar ou possuir aposentadoria urbana (prova aliás da lógica seguida por muitos magistrados de que há uma solidariedade pressuposta entre os cônjuges e de que a mulher é dependente do esposo, apenas precisando trabalhar na roça se for solteira, viúva ou tiver marido ou filho doente), a compreensão de que a atividade é principal quando exercida para garantir a mera "sobrevivência" da família, tem mantido o prejuízo principalmente à mulher casada cujo salário ou pensão do esposo ultrapasse certo patamar. A compreensão de regime de economia familiar dessa forma pressupõe sempre uma solidariedade entre os cônjuges.

É verdade. Pode ser entendido dessa maneira, ou seja, é um critério formal. Nem sempre é o critério justo a depender do caso concreto. Pode acontecer de um cônjuge receber bem e não repassar nada para a família. Mas a gente trabalha com as regras da experiência e com a forma, assim, de tornar o direito previsível, estabelecendo critérios que tornem as decisões justas na maioria dos casos. Eu trabalho assim (Entrevista 04).

Percebe-se, assim, que na praxe judicial muitos magistrados têm construído um critério abstrato e formal para caracterizar o que é plenamente lacunoso e subjetivo. A lei não fixa qualquer valor máximo a ser percebido por um dos cônjuges para que o outro "não precise trabalhar" e por isso "não mereça" receber a aposentadoria especial como segurado especial. Não obstante, estes posicionamentos de depen- 
dência entre os cônjuges e o padrão de miserabilidade têm sido repetidos pelos magistrados. A primazia dada à previsibilidade, em alguns casos, pode dar margem a francas arbitrariedades e injustiças.

\section{Considerações finais}

Embora a tarefa dos operadores do direito, indiscutivelmente, seja pautada no corpo legal e jurisprudencial e enfrente dificuldades diversas quanto à prova dos fatos, a tradição que toma o sistema jurídico por abstrato e assexual não deixa os juristas perceberem que na busca pela "verdade real" sobre a condição de trabaIhador do autor, eles tomam posições culturais a respeito das relações sociais no meio rural.

Substituir "agropecuária", expressão legal e mais ampla, por "agricultura" significa adotar também outros termos carregados de conteúdo e demarcados pela divisão sexual do trabalho no campo e na família: "roçado", "enxada", "trabalho pesado". Os(as) magistrados(as), nas audiências e sentenças, têm muitas vezes validado as relações ideológicas e desiguais que configuram os significados das práticas no âmbito da agricultura e pecuária familiares. Algumas tecnologias de gênero expressas nas falas dos próprios autores são também refletidas no modelo de estratégias produtivas das famílias como pensado pelos magistrados.

Três fatores influenciam o fato de o trabalho no roçado, com o uso da enxada, ser a fachada social através da qual os magistrados tentam acessar o universo de vida e trabalho das partes: a maior frequência desse tipo de labor tanto como suprimento alimentar da família quanto meio de ocupação na zona rural nordestina; a desvalorização das atribuições produtivas que são destinadas culturalmente às mulheres, como o trabalho na horta e a criação dos animais; a facilidade de caracterizar o trabalho na roça por meio dos sinais incorporados ao corpo do(a) trabalhador(a) ao longo dos anos, especialmente aquele executado com a enxada.

No tocante à inspeção judicial, que não é um critério legal ou jurisprudencial e sim construído na prática dos juizados especiais, ela tem se mostrado importante elemento de convicção dos magistrados. Todavia, não é possível definir um padrão para sua utilização. Alguns magistrados conferem maior valor a essa espécie de prova por acreditarem em sua credibilidade acostada à experiência que já têm a partir do contato pessoal anterior com muitos segurados. Ela seria uma prova da fachada social difícil de ser forjada. Outros não fundamentam habitualmente suas decisões nas características físicas do autor. 
O uso exagerado ou peso demasiado conferido à inspeção judicial pode ser extremamente desfavorável às mulheres, especialmente as casadas, visto que, a depender da região paraibana, o labor com a enxada está mais reservado aos homens. Se a mulher efetivamente não trabalhar com a enxada, mas plantar e colher, responderá com mais clareza às perguntas "técnicas" feitas pelos magistrados acerca das espécies de plantação e dos modos de trabalho. Porém, se o cerne de suas atividades produtivas for o quintal, por exemplo, os cuidados com a horta e os animais, ela terá poucas chances de ter seu pedido de aposentadoria reconhecido, pois precisará criar uma performance muito distante de sua realidade para historicizar seu modo de vida na fachada social da agricultura, da roça e da enxada.

Por outro lado, o conjunto das entrevistas e dos processos analisados demonstram que todos os magistrados reconhecem a dificuldade adicional que as mulheres solteiras e sem filhos têm para produzir provas documentais. Embora recentemente esse quadro esteja mudando, os processos de aposentadoria referem-se a um histórico de vida de muitos anos atrás.

O aspecto certamente mais desfavorável às mulheres, entretanto, corresponde às concepções predominantemente adotadas pelos magistrados acerca do regime de economia familiar e de subsistência. Os magistrados reconhecem o conteúdo aberto da prescrição legal a ser preenchido nos casos concretos. Contudo, percebeu-se que no microcosmo dos JEFs construiu-se uma prática regular, a fim de conferir previsibilidade às suas decisões: um padrão eminentemente financeiro, que encontra "respaldo" na fictícia solidariedade entre os cônjuges e membros da família.

Ora, a pluriatividade, em vez de ser interpretada como algo positivo no meio familiar, acaba diminuindo o valor do trabalho rural dos outros membros familiares, particularmente o feminino. A conclusão a que se chega, portanto, é que os magistrados trocam as palavras da lei "subsistência e desenvolvimento socioeconômico" do grupo familiar por "sobrevivência", "escapar à fome".

Por fim, a solidariedade fictícia a que os magistrados atribuem à lei é particularmente grave às mulheres. Sabido que a distribuição de bens e de poder na família não é equivalente. Hierarquizada que é a família pressupor uma solidariedade abstrata entre os cônjuges é o mesmo que desestimular o empoderamento feminino e, no caso concreto, pode resultar na negativa de direitos e na institucionalização e aprofundamento de desigualdades reais. 


\section{Rural actresses or rural workers?}

The theater and the facade to obtain special rural retirement

Abstract: This article concerns about gender inequalities in the judicial discourse and practices under special federal courts. The trial of the lawsuits of rural special retirement is mainly held by special federal courts (Juizados Especiais Federais - JEFs). For the demarcation of the cases, the judges must decide whether the plaintiff is a special rural insured, a task that involves a lot of legal concepts and subjective interpretations in the microcosm of judicial practice. Based on Erving Goffman teatrology, interviews, hearings and rulings of Paraiba JEFs were analyzed for gender inequalities in the discourse of the actors involved in social interaction. Particularly, he understandings given to labor and rural individually or in a household system working were studied. It was observed that the ideas of "light" work and "heavy" work were used as "technologies of gender" for classifying and regulating who is the special rural insured, inserting it in a familiar and predictable social facade, which, on the other hand, is very restricted and may consequently generate potential injustices.

Keywords: family farming, judicial discourse, theatrology, technologies of gender, female rural retirement.

\section{Referências}

AQUINO, Luseni et alii. Acesso à Justiça Federal: dez anos de juizados especiais. Brasília: Ipea; Conselho da Justiça Federal; Centro de Estudos Judiciários, 2012.

FONSECA, Regina Lúcia Teixeira Mendes da. Dilemas da decisão judicial. As representações de juízes brasileiros sobre o princípio do livre convencimento motivado. Rio de Janeiro: Universidade Gama Filho, 2008.

FOUCAULT, Michel. História da sexualidade I: a vontade de saber. 13 ed. Rio de Janeiro: Edições Graal, 1999.

GOFFMAN, Erving. A representação do eu na vida cotidiana. 10a ed. Petrópolis: Vozes, 2002.

LAURETIS, Teresa de. La tecnología del género. Tradução de Ana María Bach e Margarita Roulet, de Technologies of gender. Essays on theory, film and fiction. Londres: Macmillan Press, p. 1-30, 1989.

NARDELLI, Luis Fernando. Inspeção judicial. Carta forense, 2014. Disponível em: <http://www.cartaforense.com.br/conteudo/entrevistas/inspecao-judicial/1443>.

NEVES, M.; COSTA, B. Relações de gênero, informalidade e experiências de economia solidária. In: ÁVILA, M. B.; PRADO, M.; SOUZA, T. SOARES, V.; FERREIRA, V. (Orgs.). Reflexões feministas sobre informalidade e trabalho doméstico. Recife: SOS Corpo, 2008. 
PAULILO, Maria Ignez. O peso do trabalho leve. Revista Ciência Hoje, n. 28, 1987. Disponível em: <http://nafa.paginas.ufsc.br/files/2010/09/OPesodoTrabalhoLeve. pdf>. Acesso em: 24 Jan. 2014.

- Trabalho familiar: uma categoria esquecida de análise. Revista Estudos Feministas, v. 12, p. 229-252, Jan./Abr. 2004.

PORTELLA, A. P.; SILVA, C. Divisão sexual do trabalho em áreas rurais do Nordeste do Brasil. In: SCOTT, P.; CORDEIRO, R. (Orgs.). Agricultura familiar e gênero: práticas, movimento e políticas públicas. Recife: Editora UFPE, 2006.

RUFINO, Isaura; ALBUQUERQUE, Lígia. Elementos que dificultam a participação da mulher no processo de reforma agrária. In: Política fundiária no Nordeste. Brasília: Fundaj/Ipea, 1986.

SCHNEIDER, Sérgio. Teoria social, agricultura familiar e pluriatividade. Revista Brasileira de Ciências Sociais, v. 18, n. 51, p. 99-121, 2003.

SILVA, Carolina Braz de Castilho E; SCHNEIDER, Sergio. Gênero, trabalho rural e pluriatividade. In: SCOTT, Parry; CORDEIRO; Rosineide e MENEZES, Marilda (Orgs.). Gênero e geração em contextos rurais, p. 183-207. Florianópolis, Ed. Mulheres, 2010. 